\title{
ZAGROŻENIA BIOLOGICZNE DOCIEPLANYCH ŚCIAN ZEWNĘTRZNYCH BUDYNKÓW MIESZKALNYCH
}

\begin{abstract}
Ściana zewnętrzna budynków mieszkalnych oprócz funkcji konstrukcyjnej wydzielenia przestrzeni bytowania człowieka pełni również istotną funkcję ochronną dla środowiska wewnętrznego. We współczesnym, energooszczędnym budownictwie właśnie ta rola ściany stała się zagadnieniem bardzo istotnym. Przyczyną istotnych zmian w technologii wykonywania ścian stał się obecnie wymóg oszczędzania energii. Nie należy jednak zapominać, że podstawową funkcją tych konstrukcji powinno być dostosowywanie warunków środowiska geograficznego do potrzeb środowiskowych, klimatycznych i zdrowotnych, człowieka. Z uwagi na wymóg energooszczędności istniejące budynki mieszkalne poddawane są w ostatnich latach modernizacji termicznej poprzez docieplanie ich ścian zewnętrznych. Obserwacja modernizowanych obiektów ukazuje, że zastosowane w tym procesie technologie budowlane są bardziej podatne na rozwój korozji biologicznej niż miało to miejsce w tzw. tradycyjnym budownictwie. Celem pracy jest podniesienie problemu wyraźnie zwiększonego zakresu zagrożeń biologicznych w tych rozwiązaniach. Zjawisko to jest niezwykle niekorzystne i to nie tylko w zakresie trwałości materialnej struktury budowlanej i walorów estetycznych tej architektury. Szczególnie istotny jest zakres zagrożeń tego zjawiska w kontekście profilaktyki prozdrowotnej i postępu wiedzy medycznej na temat wpływu czynników mikrobiologicznych środowiska wewnętrznego pomieszczeń mieszkalnych na zdrowie człowieka. Pierwotnie technologie docieplania ścian zewnętrznych w systemie tzw. ścian dwuwarstwowych dopuszczone zostało jedynie w procesie modernizowania istniejących obiektów. Obecnie technologie tego typu są powszechnie stosowane także w nowoprojektowanych budynkach mieszkalnych. Rozwój zagrożeń biologicznych pojawiający się na modernizowanych obiektach już w krótkim czasie po dociepleniu skłania do analizy przyczyn tego zjawiska. Konieczne staje się określenie wymogów jakie powinny spełniać technologie budowlane stosowane w konstrukcji energooszczędnych ścian zewnętrznych w celu ochrony środowiska zbudowanego przed rozwojem zagrożeń biologicznych.
\end{abstract}

Słowa kluczowe: korozja mikrobiologiczna, przegrody budowlane, środowisko wewnętrzne, warunki zdrowotne

\footnotetext{
${ }^{1}$ Teresa Kusionowicz, Politechnika Krakowska, Wydział Architektury, Zakład Technik Budowlanych w Instytucie Projektowania Budowlanego, ul. Warszawska 24, 31-155 Kraków; tel. 12374 2456; tkusionowicz@pk.edu.pl
} 


\section{Wprowadzenie}

Ściana zewnętrzna budynku jest bardzo ważnym elementem kształtowania odpowiednich dla wymogów organizmu człowieka warunków w miejscu jego zamieszkania. W naszej strefie klimatycznej w środowisku tym człowiek spędza ok. $80 \%$ swojego życia. W związku z tym uzyskanie prawidłowych dla organizmu człowieka warunków środowiskowych w budynkach mieszkalnych jest niezwykle ważne dla realizacji potrzeb fizycznych naszego organizmu i cennym elementem profilaktyki prozdrowotnej [1]. W obecnej sytuacji ekonomicznej przy coraz wyższych kosztach ponoszonych na leczenie ludzi chorych, zagadnienie profilaktyki prozdrowotnej ma ogromne znaczenie zarówno ekonomiczne, ale przede wszystkim społeczne. Prowadzenie profilaktyki prozdrowotnej powinno być udziałem wszystkich dziedzin naszej działalności[2,3]. Działalność budowlana, szczególnie w zakresie realizacji budynków mieszkalnych, miejsca tak ważnego pod względem warunków bytowania człowieka, wydaje się w tej dziedzinie szczególnie istotna i znacząca. Dlatego niepokoi fakt, że w szeroko zakrojonym planie oszczędzania energii w budownictwie i wdrażaniu w budownictwie mieszkaniowym nowych energooszczędnych technologii dochodzi do rozwoju zjawisk biologicznych. W porównaniu do obiektów realizowanych w przeszłości widoczne są istotne zmiany w zakresie występowania tego zagrożenia. Pojawienie się w strukturze budowlanej zjawisk biologicznych, które mogą mieć negatywny wpływ nie tylko na trwałość konstrukcji, ale także na nasze zdrowie wymaga szczególnej uwagi i szybkiej reakcji zmierzającej do poprawy tej sytuacji.

\section{Korozja biologiczna ścian w technologii tradycyjnej - konstrukcje jednowarstwowe}

Ściana zewnętrzna budynku w warunkach klimatycznych naszego kraju przez znaczną część roku narażona jest na zawilgocenie na skutek opadów atmosferycznych deszczu i śniegu. Analizowane w tej części ściany zewnętrzne budynków mieszkalnych budownictwa tradycyjnego wykonywane były jako konstrukcje jednowarstwowe $\mathrm{z}$ jednego rodzaju materiału. $\mathrm{Z}$ uwagi na brak szczelności materiału ich struktury i ograniczone właściwości izolacyjności termicznej dyfundująca przez te przegrody para wodna na skutek wychłodzenia ulegała wykropleniu w ich wnętrzu. Przyczyniało się to zapewne do dodatkowego zawilgocenia materiału tych ścian w sezonie zimowym.

W tradycyjnym budownictwie rozwojem procesów biologicznych zagrożone były przede wszystkim konstrukcje drewniane, ale zagrożenie to dotyczyło także ścian murowanych. Zawilgocenie materiału jest czynnikiem sprzyjającym rozwojowi korozji biologicznej, ale tylko w przypadku przedłużającego się w czasie występowania tego zjawiska[4]. Na elewacyjnej, wilgotnej powierzchni ścian zewnętrznych, dzięki dostępowi do naturalnego oświetlenia, zasiedlają się mikroorganizmy z rodzaju mchów i porostów. Zielone zabarwienie tych mikroorgani- 
zmów jest wyraźnie widoczne na elewacji budynku. Podkreślić jednak w tym miejscu należy, że nie dochodzi do rozwoju takiego procesu na materiale, który jest zawilgocony tylko przez krótki okres czasu i ulega szybkiemu wysuszeniu.

Do analizy zakresu zagrożeń biologicznych $\mathrm{w}$ budynkach mieszkalnych o tradycyjnej konstrukcji jednowarstwowych ścian zewnętrznych wybrane zostały na terenie miasta Krakowa dwa rodzaje obiektów: pierwsze wybudowane na przełomie XIX i XX wieku i drugie zrealizowane w latach pięćdziesiątych XX wieku w dzielnicy Karkowa - Nowej Hucie. W wybranych obiekty elewacyjna powierzchnia ścian zachowała się $\mathrm{w}$ niezmienionym stanie, nie była odnawiana i była narażona na opady atmosferyczne przez niezwykle długi okres czasu.

Prawidłowo wykonane i zabezpieczone przed kapilarnym podciąganiem zawilgocenia części nadziemne ścian w budynkach pierwszego rodzaju nie podlegają korozji biologicznej, pomimo wieloletniego funkcjonowania. Wyprawy zewnętrzne tych ścian ulegają co prawda znacznym uszkodzeniom na skutek odspajania tynku w wyniku zamarzania wilgoci, to jednak pomimo systematycznego, ale czasowego zawilgocenia ich struktury nie noszą śladów rozwoju mikroorganizmów. Wyprawy elewacyjne na tych ścianach podlegają jedynie zmęczeniu materiału i odspojeniu od konstrukcji muru - przykłady rys. 1. W przypadku szczelnych powłok malarskich dochodzić może do ich złuszczania. Zniszczenie zewnętrznej powłoki tych ścian może także powstać na skutek krystalizacji soli.
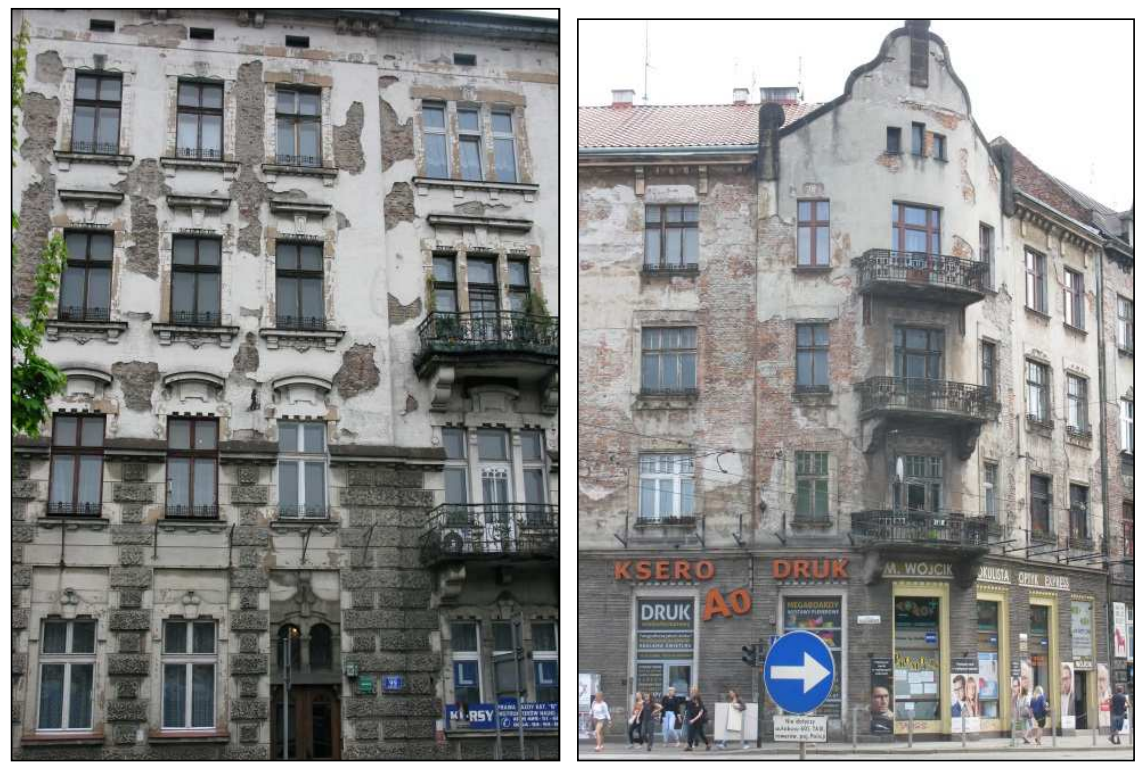

Rys. 1. Uszkodzenia tynków na elewacjach zabytkowych budynków w Krakowie (fot. T. Kusionowicz)

Fig. 1. Damages of plasters on elevations of historical buildings in Cracow (photo T. Kusionowicz) 
W budynkach tych objawy występowania zagrożeń biologicznych znajdują się jedynie w strefie podziemnej i przyziemnej. W budynkach wykonanych w tym czasie bardzo często brak jest odpowiedniego zabezpieczenia przed wilgocią podziemnych części ścian zewnętrznych. Skutkuje to rozwojem zagrożeń biologicznych w strefie piwnic i przyziemnych fragmentów tych ścian. Zjawisko to ma charakter narastający na skutek kapilarnego podciągania wilgoci. Z uwagi na zagłębienie $\mathrm{w}$ ziemi wysychanie tego fragmentu ich struktury jest bardzo utrudnione, szczególnie w przypadku źle wietrzonych piwnic. Dodatkowo mikroorganizmy dbając o swoje przetrwanie starają się i to skutecznie przeciwdziałać wysuszeniu materiału. Dzięki temu zasiedlone w strukturze materialnej mchy i porosty po stronie zewnętrznej, a pleśnie i grzyby po stronie wewnętrznej systematycznie powiększają zakres swojego występowania. Obejmują coraz większy zakres części cokołowej ściany zewnętrznej także na skutek dodatkowego zawilgocenia odbitymi wodami opadowymi. W analizowanych budynkach poziom mieszkalny położony jest znacznie ponad terenem i dzięki temu te niekorzystne zjawiska znajdują się głównie w strefie piwnic.

Rozwój zagrożeń biologicznych jest uwarunkowany między innymi sposobu zewnętrznego ukształtowania ściany i jej orientacji względem stron świata. Istotne znaczenie ma także zwiększone zacienienie oraz utrudniony przepływ powietrza przy powierzchni ściany Rozwój mikroorganizmów, głównie w postaci glonów i porostów, rzadziej grzybów, dotyczy przede wszystkim elewacji północnych i zachodnich. Ważnym elementem profilaktyki tego szkodliwego zjawiska jest na pewno osłonięcie zewnętrznej strony ściany wyraźnie wysuniętym okapem dachu. Zabieg ten $\mathrm{w}$ istotnym zakresie ogranicza powierzchnię ściany, która jest narażona na bezpośrednie zawilgocenie wodami opadowymi. Podobnie ochronną, oprócz oczywiście estetycznej i w jakimś zakresie konstrukcyjnej funkcji pełnią gzymsy międzypiętrowe i nadokienne. Elementy te, wystające z lica ściany odsuwają od niej strumień wody opadowej i chronią ją na znacznych fragmentach przed intensywnym zawilgoceniem. Gzyms pokrywane były dachówką, a zastosowanie tego rodzaju pokrycia wymagało odpowiedniego nachylenia górnej ich powierzchni. Nachylenie to zweryfikowane zostało korzystnie przez czas, ponieważ dzięki tak ukształtowanej powierzchni woda opadowa nie jest odbijana w kierunku lica ściany i dzięki temu jej struktura materialna nie ulega skumulowanemu zawilgoceniu, bezpośrednio wodą opadową i odbitą wodą opadowa. Ograniczenie intensywności zawilgocenia umożliwia szybsze jej wysuszenie, co skraca czas zawilgocenia materiału ściany i chroni go przed rozwojem mikroorganizmów.

Ważną rolę $\mathrm{w}$ zakresie zapobiegania rozwojowi zagrożeń biologicznych pełniły wyprawy tynkarskie, w których stosowano domieszkę wapna. Wapno jest doskonałym materiałem „dezynfekującym”, uniemożliwiającym zasiedlenie struktury materialnej przez mikroorganizmy. Wyprawy stosowane w budownictwie tradycyjnym nie tworzyły szczelnych warstw. Jednorodna struktura murowanych ścian zewnętrznych także umożliwia swobodną dyfuzję pary wodnej 
przez przegrodę. Jest to, co prawda, w jakimś stopniu niekorzystne $\mathrm{z}$ uwagi na ich izolacyjność termiczną, ale przyśpiesza wysuszenie zawilgoconej powierzchni ścian zewnętrznych, co było i jest chyba nadal najskuteczniejszą metodą zapobiegania rozwojowi zagrożeń biologicznych.

Analiza zachowanych w swojej pierwotnej formie ścian zewnętrznych budynków mieszkalnych w Nowej Hucie odnosi się do obiektów powstałych na przełomie lat pięćdziesiątych i sześćdziesiątych wykonanych także tradycyjną, murowaną metodą budowania. Jednorodne materiałowo konstrukcje tych ścian zostały zweryfikowane ponad sześćdziesięcioletnim funkcjonowaniem. Obserwacja ich ukazuje kolejne aspekty w odniesieniu do problemu rozwoju zagrożeń biologicznych na zewnętrznej powierzchni ścian zewnętrznych. W porównaniu do poprzednio omówionych konstrukcji na uwagę zasługuje fakt, że widoczny zielonym nalotem rozwój mikroorganizmów występuje na ich powierzchni nie tylko w strefie cokołowej, ale także ponad gzymsami i elementami dostawionymi lub wystającymi z elewacji. Zarówno w części cokołowej, jak i ponad gzymsami pojawienie się zagrożeń biologicznych spowodowane jest zwiększonym zawilgoceniem tych fragmentów, nie tylko samymi wodami opadowymi, ale dodatkowo odbitymi wodami opadowymi - przykłady rys. 2 .
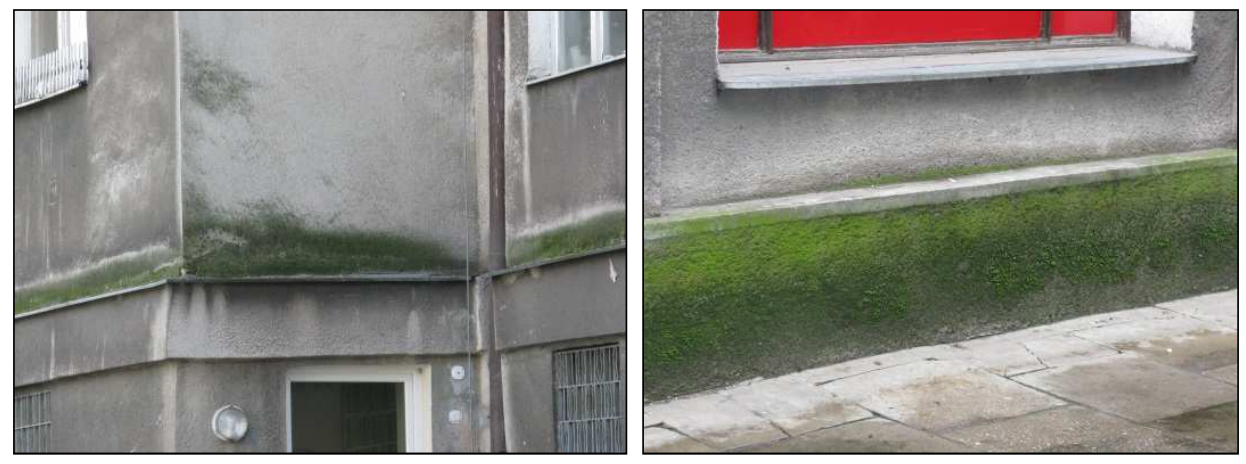

Rys. 2. Rozwój korozji biologicznej na ścianach budynków mieszkalnych w najstarszej części Nowej Huty w Krakowie (fot. T. Kusionowicz)

Fig. 3. Up growth biological corrosion on the walls of residential buildings in the oldest district of Nowa Huta in Cracow (photo T. Kusionowicz)

O ile rozwój procesów biologicznych w partii cokołowej ściany jest zjawiskiem, z którym budownictwo zmaga się od zarania, i jak na razie mało skutecznie, to niepokojący jest fakt pojawienia się tego rodzaju procesów ponad gzymsami i uskokami w licu ściany. Elementy te odegrały istotną rolę w estetycznym kształtowaniu elewacji badanych obiektów. Porównanie z wcześniej omówionymi obiektami, w których pomimo występowania licznych gzymsów i zwieńczeń nadokiennych nie dochodzi do zasiedlenia mikroorganizmów, pokazuje że istotną przyczyną pojawienia się tego zjawiska na obiektach Nowej Huty jest 
sposób zabezpieczenia tych elementów. Gzymsy w tych budynkach zostały od góry zabezpieczone przed wodami opadowymi tzw. obróbką blacharską, która z uwagi na swoją większą niż dachówki szczelność nie wymaga większego kata nachylenia. Niestety nie wzięto pod uwagę faktu, że mały kąt jej nachylenia jest niekorzystny w zakresie odbitej wody opadowej. Obecnie mankament ten jest weryfikowany i wspólnoty mieszkańców dostrzegając ten problem decydują o wymianie dotychczasowej obróbki na nową o znacznie zwiększonym kącie nachylenia - przykład rys. 3 .
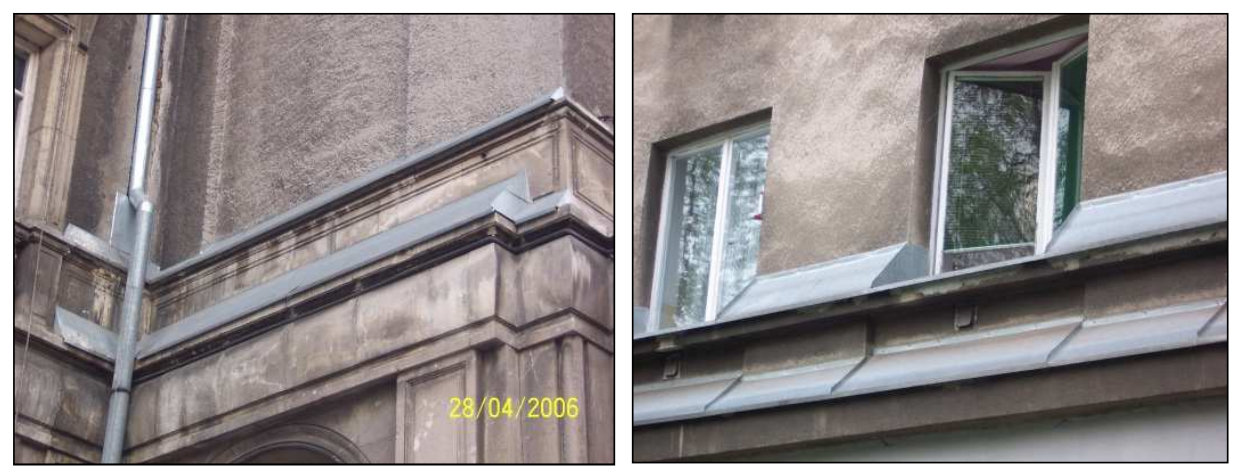

Rys. 3. Nowe obróbki blacharskie gzymsów na ścianach budynków mieszkalnych w najstarszej części Nowej Huty w Krakowie (fot. T. Kusionowicz)

Fig. 3. New tinner roofing on wall of residential buildings in the oldest district of Nowa Huta in Cracow (photo T. Kusionowicz)

\section{Korozja biologiczna ścian o konstrukcji dwuwarstwowej}

Z uwagi na wymóg energooszczędności istniejące budynki mieszkalne poddawane są w ostatnich latach modernizacji termicznej poprzez docieplanie ich ścian zewnętrznych. Obserwacja modernizowanych obiektów ukazuje, że zastosowane w tym procesie technologie budowlane są bardziej podatne na rozwój korozji biologicznej niż miało to miejsce $\mathrm{w}$ tzw. tradycyjnym budownictwie. Pierwotnie technologie docieplania ścian zewnętrznych w systemie tzw. ścian dwuwarstwowych dopuszczone zostały do stosowania jedynie w procesie termomodernizacji istniejących obiektów. Obecnie technologie tego typu są coraz powszechniej stosowane także w nowoprojektowanych budynkach mieszkalnych.

W ramach omawianego zagadnienia zagrożeń biologicznych docieplanych ścian zewnętrznych na szczególna uwagę zasługują budynki mieszkalne, w których w procesie termomodernizacji zastosowane zostały rozwiązania polegające na przyklejaniu i kotwieniu materiału termoizolacyjnego do konstrukcji i wykonaniu wyprawy tynkarskiej na siatce $\mathrm{W}$ porównaniu do budynków wykonywanych metodami tradycyjnymi $\mathrm{w}$ wielu budynkach mieszkalnych docieplanych 
tego rodzaju metodami zakres rozwoju zagrożeń biologicznych na powierzchni elewacji jest znacznie większy i postępuje wyraźnie szybciej - przykłady rys. 4. Zwiększony zakres tego zjawiska jest istotnym zagrożeniem dla jakości zdrowotnej środowiska w pomieszczeniach. Oprócz miejsc tradycyjnie już narażonych na rozwój zjawisk biologicznych na skutek kumulacji wilgoci opadowej i wilgoci odbitej w kierunku ściany, nad występami, gzymsami czy daszkami, w ścianach tych zielone naloty, świadectwo rozwoju mchów i porostów, pojawiają się na całej powierzchni elewacji. Zjawiska tego nie obserwujemy na budynkach wykonanych metodami tradycyjnymi i funkcjonujących już od wielu lat. Natomiast w budynkach docieplanych rozwój mikroorganizmów jest już wyraźnie widoczny po zaledwie 5 latach od jego wykonania. Mchy i porosty utrzymując zawilgocenie struktury ściany i w efekcie tego dochodzi do narastającego zawilgocenia wewnątrz przegrody. To z kolei prowadzi do pojawienia się grzybów i pleśni po stronie wnętrza [5]. O ile mchy i porosty nie stanowią bezpośredniego zagrożenia dla naszego zdrowia, to pleśnie i grzyby są dla nas ogromnym zagrożeniem biologicznym.
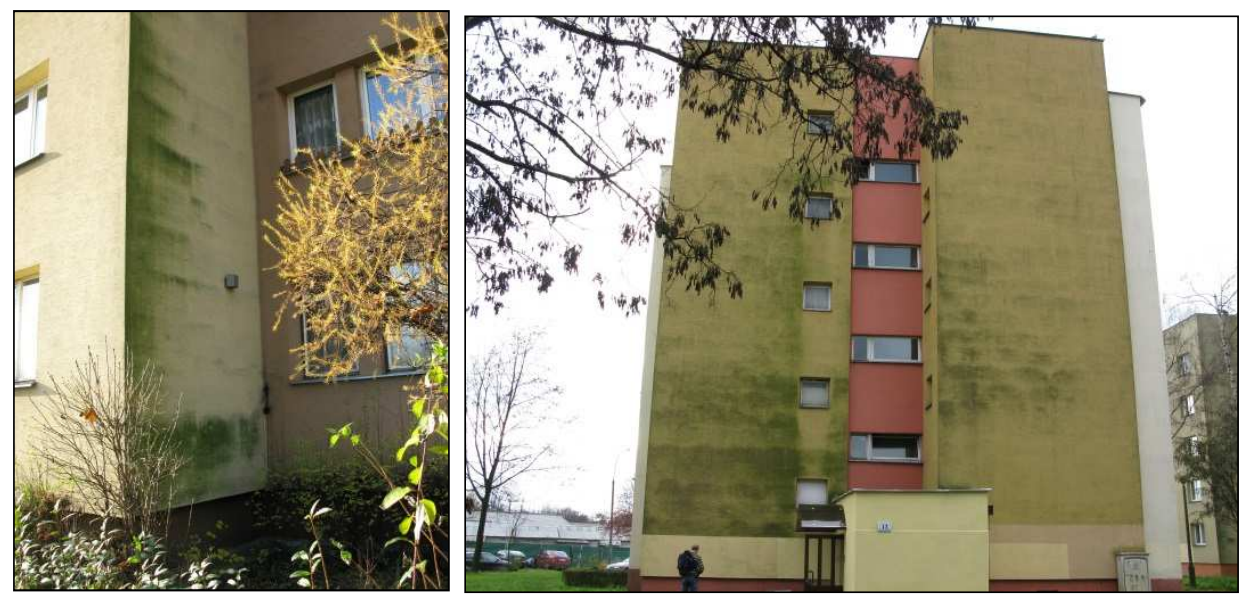

Rys. 4. Rozwój korozji biologicznej na docieplanych ścianach zewnętrznych budynków mieszkalnych w Nowej Hucie w Krakowie (fot. T. Kusionowicz)

Fig. 4. Up growth biological corrosion on the warming up external walls of residential buildings of Nowa Huta in Cracow (photo T. Kusionowicz)

Obserwacja budynków i analiza rozwiązań wskazuje na wiele przyczyn tego zjawiska. Za zdecydowanie zasadniczą uznać należy stosowanie szczelnych wypraw elewacyjnych. Stosowanie takich tynków zaburza prawidłowe funkcjonowanie całej przegrody pod względem cieplno-wilgotnościowym [6]. Zgodnie $\mathrm{z}$ obowiązującymi $\mathrm{w}$ przeszłości przepisami zewnętrzne przegrody warstwowe powinny być konstruowane z zachowaniem malejącego oporu dyfuzyjnego materiałów poszczególnych warstw [7]. Takie ułożenie materiałów umożliwia 
sprawną dyfuzję pary wodnej z wnętrza na zewnątrz. Szczelne wyprawy elewacyjne stosowane $\mathrm{w}$ systemach termomodernizacji budynków nie spełniają tego wymogu, niezależnie od parametrów materiału izolacji termicznej.

Znowelizowane przepisy normujące zasady energooszczędności w konstruowaniu budynków nie precyzują wymogu układu warstw w przegrodach zgodnego z malejącym oporem dyfuzyjnym materiałów. Umożliwia to dowolność stosowania materiałów izolacji termicznej w docieplanych przegrodach. Dyfuzja pary wodnej $\mathrm{w}$ tych przegrodach, nawet w sytuacji zastosowania szczelnych płyt styropianowych jest kontynuowana poprzez styki tych płyt i punkty kotwienia. Zastosowanie szczelnej wyprawy uniemożliwia dalszą dyfuzje pary wodnej i prowadzi do jej wykroplenia pod powierzchnią tynku. Powoduje to narastające zawilgocenie materiału izolacji termicznej i osłabia jej funkcjonowanie pod względem izolacji cieplnej. Wysuszenie takiego zawilgocenia jest niezwykle utrudnione na skutek szczelności wyprawy zewnętrznej. W wyniku przedłużającego się zawilgocenia struktury wewnątrz przegrody dochodzi do rozwoju zagrożeń biologicznych, które przyczyniają się do systematycznego narastania tego zjawiska. Kolejnym etapem tego procesu jest deformacja powierzchni elewacji i jej uszkodzenie, co dodatkowo pogarsza sytuację wilgotnościową wnętrza przegrody. Podlega ona dodatkowemu zawilgoceniu na skutek opadów atmosferycznych wilgocią przedostającą się w miejscach uszkodzeń do jej wnętrza. W tej sytuacji podstawowe założenie wykonywania szczelnego tyn$\mathrm{ku}$, jakim jest zabezpieczenie przed wodami opadowymi nie funkcjonuje zgodnie z naszymi oczekiwaniami.

Utrzymanie szczelności cienkiej wyprawy tworzonej na bazie tworzyw sztucznych jest w praktyce budowlanej praktycznie niemożliwe do uzyskania. Wyroby wykonywane na bazie tworzyw sztucznych podlegają procesowi tzw. „starzenia się" w trakcie, którego tracą swoją elastyczność. Sztywna warstwa na powierzchni zewnętrznej ściany podlega $w$ naszych warunkach klimatycznych dużym, dobowym wahaniom temperatury. Wykonywanie takich wypraw na dużych powierzchniach, bez dylatacji umożliwiających ich wydłużenie liniowe skutkuje powstawaniem licznych mikropęknięć. Zastosowanie przezbrojenia tej warstwy siatkami z włókna szklanego, kotwionymi razem z materiałem izolacyjnym, nie zapobiega jej spękaniu. Tynki tracące swoje właściwości plastyczne stają się mniej odporne na naciski spowodowane parciem wiatru, co także podnosi ryzyko spękania powłoki zewnętrznej i przyczynia się do zaburzenia jej szczelności. Bardzo istotnym zagadnieniem w zakresie możliwości spękania wyprawy elewacyjnej jest sztywność i rozszerzalność cieplna materiału podłoża, na którym oparty został tynk. Koniecznością staje się obecnie usuwanie tych mikroorganizmów z powierzchni ścian, nie jest to jednak takie proste, a zabiegi stosowane w tym celu są aktualnie na etapie testowania. Celowe wydaje się poświęcenie temu zagadnieniu odrębnego opracowania, kiedy odpowiedni czas zaświadczy o ich skuteczności. 
Obserwacja rozwoju zjawisk biologicznych na elewacjach docieplanych budynków wyraźnie ukazuje, że jest to możliwe jedynie dzięki licznym pęknięciom wypraw tynkarskich i wilgoci utrzymującej się w takich mikropęknięciach. Stopniowe narastanie zakresu i intensywności tego zjawiska wyraźnie sugeruje, że prawdopodobnie $\mathrm{w}$ wyniku nieszczelności i rozwoju mikroorganizmów dochodzi do kumulowania wilgoci na styku izolacji termicznej i wyprawy zewnętrznej. Szczelny tynk uniemożliwia wysuszenie tej wilgoci, w przeciwieństwie do tradycyjnych tynków, w których nie obserwujemy tego rodzaju zjawisk. Dodatkowo zawilgocenie materiału izolacyjnego zmniejsza jego właściwości ochrony termicznej, co prowadzi do zaburzeń w zakresie cieplnowilgotnościowego funkcjonowania przegrody i może prowadzić do powstawania licznych zagrożeń komfortu cieplnego w pomieszczeniach. W ramach realizacji potrzeb biologicznych człowieka $\mathrm{w}$ architekturze staje się istotnym problemem w odpowiednim dla naszego organizmu kształtowaniu środowiska wewnętrznego.

\section{Wnioski}

Widoczny na ścianach docieplanych budynków mieszkalnych rozwój zjawisk biologicznych jest niekorzystny dla prawidłowego funkcjonowania ścian zewnętrznych i ich trwałości. Prowadzi do rozwoju zagrożeń biologicznych w ich strukturze, w efekcie którego dochodzi do pojawienia się szkodliwych czynników biologicznych w środowisku pomieszczeń mieszkalnych. Fakty te skłaniają do weryfikacji technologii budowlanych stosowanych w procesach termomodernizacji. W ramach profilaktyki prozdrowotnej i środowiskowej powinniśmy zadbać o wyeliminowanie ze stosowania technologii, które nie sprawdziły się w praktyce i stanowią istotne zagrożenie zarażenia zjawiskami biologicznymi struktury budowlanej, szczególnie w przypadku budynków mieszkalnych. Istotną rolę $\mathrm{w}$ tym zakresie powinny odegrać przepisy normatywne i prawne, które jako jedyne są w stanie przeciwdziałać względom ekonomicznym, które zdominowały we współczesnym budownictwie mieszkaniowym naszego kraju dobór technologii budowlanych $\mathrm{w}$ procesach realizacji deweloperskiej tego rodzaju inwestycji.

\section{Literatura}

[1] Jethon Z., Grzybowski A. (red.): Medycyna zapobiegawcza i środowiskowa, Wyd. Lek. PZWL, Warszawa 2000.

[2] Kusionowicz T.: Problemy projektowania budynków mieszkalnych a zdrowie człowieka. Wybrane zagadnienia. Politechnika Krakowska, Kraków 2008.

[3] Banaś L.: Przegrody budowlane zdrowych budynków. Przegląd Budowlany nr 11/1995.

[4] Zyska B.: Zagrożenia biologiczne w budynku. Arkady Warszawa 1999. 
[5] Janińska B.: Warunki rozwoju grzybów pleśniowych w budynkach poddanych termomodernizacji, Materiały Budowlane nr 8/2000, s. 80-82.

[6] Hop T.: Konstrukcje warstwowe. Arkady Warszawa 1980.

[7] Maszewski K.: Kształtowanie przegród pod względem cieplno-wilgotnościowym. Murator nr 71/1993; s. 32-36.

\section{BIOHAZARD OF WARMING UP EXTERNAL WALL OF RESIDENTIAL BUILDINGS}

\section{S u m m a r y}

External wall in residential bulding, apart from the structural function of separating human existence sphere, has a protective function towards the internal environment. In the contemporary, energy-saving building industry this particular function of a wall has become a very significant aspect. The cause of significant changes regarding the technology of wall manufacturing is the energy-saving aspect. However it should be remembered that the primary function of such structures should be the adjustment of geographical environment conditions to environmental needs, primarily the ones regarding the climate and health aspects of a human being. The up growth of biological corrosion is significant hazards for the environment conditions in the residential buildings. In recent years, the energy saving requirement has caused that many existing residential buildings undergo thermal modernization achieved through of their external walls. Followup studies of modernized buildings indicate that the construction technologies used for this purpose are more vulnerable to the development of microbial corrosion as compared to the so-called traditional construction technologies. The aim of the thesis is to raise the issue of a significantly higher spectrum of biohazards in these solutions. This phenomenon is extremely unfavorable, not only in respect to the durability of the material building structure and aesthetic values of such architecture. The extent of such hazards in the context of health-oriented prophylaxis and the progress of medical knowledge on the impact of microbiological agents of the internal environment of living quarters on human health is of particular importance. Initially, the technologies used for external wall insulation in the so-called two-layer wall system were allowed only in existing buildings modernization. Presently, such technologies are commonly used also for newly designed residential buildings. The rise of biohazards in modernized buildings emerging soon after insulation necessitates the analysis of the reasons underlying this phenomenon. It is vital to set up the requirements for building technologies used in the construction of energy-saving external walls to protect the environment of existing living quarters against the emergence of biohazards.

Keywords: microbiology corrosion, building construction, internal environment, sanitary condition

Przestano do redakcji: $16.01 .2017 \mathrm{r}$.

Przyjęto do druku: $31.03 .2017 \mathrm{r}$. 